\title{
THE EFFECT OF PSEUDOCEDRELA KOTSCHYI (SCHWEINF.) HARMS EXTRACTS AGAINST STAPHYLOCOCCUS AUREUS GROWTH
}

Kokou Atchou $^{* 1,2,3}$, Koku Amegbo Dakey ${ }^{l, 3}$, Farida Etroubeka-Tsono ${ }^{1}$, Amégninou Agban ${ }^{l}$, Simplice Damintoti Karou ${ }^{l, 3}$, Yaovi Ameyapoh $^{1,3}$, Comlan De Souza ${ }^{l, 3}$ and Mensavi Gbeassor ${ }^{2,3}$

Address (es):

${ }^{1}$ Higher School of Biological and Food Techniques (ESTBA), University of Lome, Postal code 1515 Lome, Togo.

${ }^{2}$ Laboratory of Physiology-Pharmacology, Faculty of Sciences (FDS), University of Lome, Postal code 1515 Lome, Togo.

${ }^{3}$ Center for Research and Training on Medicinal Plants (CERFOPLAM), University of Lome, Postal code 1515 Lome, Togo.

*Corresponding author: n.k.atchou@gmail.com

ABSTRACT

\section{ABSTRACT}

https://doi.org/10.36547/be.2021.4.1.11-15

Staphylococcus aureus is a ubiquitous bacteria that causes a serious health problem because of its multi-resistance to antibiotics. The aimed of this study was to evaluate the antibacterial activity of $P$. kotschyi root against $S$. aureus ATCC 29213 and $S$. aureus, a clinical strain. The phytochemical compound was sought in the extracts by standard staining tests and extractions were carried out by fractionation using solvents depletion method with increasing polarity. The method of dilution in liquid medium was used for the antibacterial tests. The results showed that the aqueous extract of the bark was effective against both $S$. aureus with MICs of 0.39 mg.mL ${ }^{-1}$ The MICs of ethanolic extract were 0.39 and $0.78 \mathrm{mg} \cdot \mathrm{mL}^{-1}$, respectively on S. aureus ATCC 29213 and S. aureus. The steles of $P$. kotschyi roots were less effective. The ethanolic and aqueous extracts at concentrations $=2 \mathrm{MICs}$, have been respectively bacteriostatic and bactericidal effects on tested germs. The kinetics of inhibition showed that the aqueous extract of the bark at $0.78 \mathrm{mg} \cdot \mathrm{mL}^{-1}$, completely destroyed the two germs respectively in $4 \mathrm{~h}$ and $5 \mathrm{~h}$. The action of ethanolic extract at 0.78 and $1.56 \mathrm{mg} \cdot \mathrm{mL}^{-1}$ occurs late against both $S$. aureus at $6 \mathrm{~h}$ and $7 \mathrm{~h}$. Phytochemical screening revealed the presence of alkaloids, tannins, flavonoids, anthracenes, glycosides, saponosides and sterols, some of that may be responsible for the observed antimicrobial activity. This study proved the antibacterial activity of $P$. kotschyi roots that can be exploited as an antibiotic in the treatment of S. aureus infections.

Keywords: Staphylococcus aureus; Pseudocedrela kotschyi; extracts; antibacterial; bactericidal; bacteriostatic; kinetic

\section{INTRODUCTION}

Pseudocedrela kotschyi is a medicinal plant of Meliaceae family and commonly known in English as dry zone cedar or hard cedar-mahogany. It's a woody of savanna tree up to $20 \mathrm{~m}$ tall with a broad crown and fragrant white flowers (Ayo et al., 2010; Ojewale et al., 2014). The plant is commonly found in tropical West Africa and Togo. It has some biological effects as antimalarial, anticonvulsant, antibacterial, antipyretic, antidiabetic, anticancer (Ojewale et al., 2014; Elufioye et al., 2017). In traditional medicine, the plant is used to treat various diseases (Elufioye et al., 2017; Mambou et al., 2018). In West Africa, the roots of the plant are used to clean teeth (Kassim et al., 2009). In Ghana small branches and leaves are used in the treatment of malaria and abdominal pain (Asase et al., 2005)). The people of northern Côte d'Ivoire useit in the treat toothache and internal injuries (Ayo et al., 2010). In Nigeria, leaves and roots are used in the treatment of rheumatism and amoebic dysentery (Ayo et al., 2010). The interest in studying this plant lies in cultural and scientific considerations.

In rural areas, the majority of people use plants for treatment (Azzazi et al., 2015). These plants are effective, available and affordable at a lower cost and with lower side effects. An ethnobotanical survey of traditional healers in Togo identified several plants with antibiotic activity, including $P$. kotschyi, which is mainly used in the treatment abscesses. Among the bacteria responsible for this infection, S. aureus is one of the bacteria incriminated (references). S. aureus is a ubiquitous germ which is a major public health problem because it's multidrug resistance (McGuinness et al., 2017).

In order to explore novel compounds with antibiotic properties and to validate the traditional use of $P$. kotschyi, the present study was conducted to evaluate the antibacterial activity of plant roots on a S. aureus ATCC 29213 strain and a strain of $S$. aureus isolated from clinical.

\section{MATERIAL AND METHODS}

\section{Plant material}

The plant material consists of roots, bark and roots steles of Pseudocedrela kotschyi, harvested in the plateau region of Togo following an ethnobotanical survey of tradipraticians. Harvests were made at Kolocope, a village in Ogou Prefecture; about $170 \mathrm{~km}$ from Lome. They were then identified in the Laboratory of Botany and Plant Ecology of the Faculty of Sciences of the University of Lome where voucher, the specimen was deposited in the herbarium. The organs of the plant were dried at the temperature of the laboratory of ESTBA/University of Lome away from light and then reduced to powder using a Thomas Scientific ${ }^{\mathrm{TM}}$ type grinder.

\section{Microbial germs}

The germs tested consisted of a reference strain and a clinical strain of Staphylococcus:

S. aureus ATCC 29213 was from the National Institute of Hygiene (INH) of Togo

S. aureus, isolated from patients in the Bacteriology Laboratory of the Hospital of University Center (CHU Campus) (Togo).

\section{Ethnobotanical survey}

The ethnobotanical survey was conducted by semi-structured interviews of 40 traditional practitioners in ten villages in plateau and central regions of Togo (Atchou et al., 2013). The information was collected using a questionnaire submitted to the Tradipraticians during the interviews. The questions concerned plants used to treat wounds and abscesses, associated plants, other pathologies treated by the plants mentioned, the parts used, the method of harvesting organs, the vernacular name of the plants mentioned, etc.

\section{Fractional extraction}

The method used was that of the depletion of solvents with increasing polarity. It makes it possible to separate the compounds by carrying out successive extractions by passing from less polar to more polar solvents (Atchou et al., 2013; Kaouadji et al., 1986). The solvent systems used were: $\mathrm{C}_{6} \mathrm{H}_{12}=1(1 \mathrm{~h})$; $\mathrm{C}_{6} \mathrm{H}_{12}:$ Et-COO-Me $=1 / 2: 1 / 2(1 \mathrm{~h})$; Et-COO-Me =1 (6 h); Et-COO-Me : $\mathrm{CHCl}_{3}=1 / 2: 1 / 2(6 \mathrm{~h}) ; \mathrm{CHCl}_{3}=1(12 \mathrm{~h}) ; \mathrm{CHCl}_{3}: \mathrm{EtOH}=1 / 2: 1 / 2(12 \mathrm{~h})$; $\mathrm{EtOH}=1(24 \mathrm{~h}) ; \mathrm{EtOH}: \mathrm{H}_{2} \mathrm{O}=1 / 2: 1 / 2(24 \mathrm{~h}) ; \mathrm{H}_{2} \mathrm{O}=1(24 \mathrm{~h})$.

The bark and steles of the roots (100 g) were successively extracted with continuous stirring without heating using solvents in the above-mentioned order from hexane to water. After filtration on Wattman paper filter $\mathrm{n}^{\circ} 40(\varnothing 150 \mathrm{~mm})$, the filtrates were concentrated in rotary evaporator vapor type BÜCH1-114. The dry extracts obtained were placed in an oven at $45^{\circ} \mathrm{C}$ for $24 \mathrm{~h}$ and then stored in non-transparent glass vials in the refrigerator at $+4{ }^{\circ} \mathrm{C}$ for phytochemical and antibacterial tests.

\section{Antibacterial tests}

The principle is that of dilution in a liquid medium. The technique involves bringing the inoculum into contact with the extract solutions at different concentrations and then spreading them on an appropriate agar medium. 


\section{Preparation of inoculum and extract solution}

The antimicrobial tests were carried out on young cultures from 18 to $24 \mathrm{~h}$ obtained after isolation on agar medium: Chapman. The microbial suspension that served as inoculum corresponded to a turbidity of $0.5 \mathrm{Mc}$ Farland $\left(\approx 10^{6}\right.$ CFU. $\mathrm{mL}^{-1}$ ). The extracts were dissolved in distilled water and then sterilized by filtration using a $0.22 \mu \mathrm{m}$ Millipore membrane filter syringe. Their sterility was verified by seeding aliquots on Mueller-Hinton Agar Medium (MHA) for 24-48 h at $37{ }^{\circ} \mathrm{C} \pm 2{ }^{\circ} \mathrm{C}$. The tests were performed in a Microbiological Safety Station (PSM).

\section{Presumptive test}

The technique consists of putting the inoculum in contact with the extract, then seeding on agar medium. Only one concentration was used to identify the active extracts (Atchou et al., 2013; de Souza et al., 1993). A concentration of 50 mg. $\mathrm{mL}^{-1}$ of the extracts was dissolved in $2.5 \mathrm{~mL}$ of Mueller-Hinton broth (MHB) and inoculated by $50 \mu \mathrm{L}$ of inoculum $\left(1.5 \times 10^{6}\right.$ CFU.mL $\left.{ }^{-1}\right)$ for $24 \mathrm{~h}$ at the temperature of $37^{\circ} \mathrm{C}$. For the control, the extract is replaced by distilled water. Gentamicin $10 \mu \mathrm{g} \cdot \mathrm{mL}^{-1}$ was used as a control. After the $24 \mathrm{~h}$ of incubation, the preparations were spread on chapman agar medium and reincubated for 24 to 48 $\mathrm{h}$ at the temperature of $37^{\circ} \mathrm{C}$ before counting the germs. The percentage growth inhibition was calculated according to the formula:

$\%$ Inhibition of growth $=100 \times(1-$ number of colonies counted on test boxes / number of colonies counted on control boxes)

The tests were performed in a Microbiological Safety Station (PSM) and assays in triplicate.

\section{Determination of antibiotics susceptibility of bacteria}

The susceptibility curve was established for extracts that gave total inhibition of germs growth with the presumptive test. From the initial solution, a series of successive dilutions of geometric progression of reason 2 was performed to obtain a final concentration range of 50 to $0.390 \mathrm{mg} \cdot \mathrm{mL}^{-1}$. The seeding procedure remains the same as that of the presumptive test. The preparations were incubated at the temperature of $37{ }^{\circ} \mathrm{C}$ for $24 \mathrm{~h}$ and then observed with the naked eye. The presence of turbidity or deposition corresponded to the presence of microbial culture. Minimum inhibitory concentrations (MIC) were determined for the last concentrations giving no microbial culture visible to the naked eye then seeded on Chapman agar medium and incubated at the temperature of $37^{\circ} \mathrm{C}$ for $24-48 \mathrm{~h}$. The lowest concentration for which no colony was counted was considered the minimum bactericidal concentration (MBC) that can kill at least $99.99 \%$ of the initial inoculum or leave at most $0.01 \%$ of survivors $\left(10^{2} \mathrm{CFU} \cdot \mathrm{mL}^{-1}\right)$. The MBC.MIC ${ }^{-1}$ ratio allowed to evaluate the antibiotic power of the extracts: MBC.MIC ${ }^{-1} \leq 1 \Rightarrow$ bactericidal power, $\mathrm{MBC}^{\mathrm{MIC}} \mathrm{MI}^{-1} \geq 2 \Rightarrow$ bacteriostatic power (Anani et al., 2016; Karou et al., 2005).

\section{Kinetics of growth inhibition of microbial germs}

Concentrations of the extracts corresponding to twice their MIC were seeded by plating and then incubated at the temperature of $37^{\circ} \mathrm{C}$. In times $\mathrm{t}=0 ; 0.5 ; 1 ; 2 ; 3$; $4 ; 5 ; 6 ; 7 ; 8 ; 9 ; 10 ; 11 ; 12 \mathrm{~h}$ an aliquot of $100 \mu \mathrm{L}$ was removed and diluted in 100 $\mathrm{mL}$ of MHB broth and then inoculate on Chapman agar medium. The cultures were incubated at the temperature of $37{ }^{\circ} \mathrm{C}$ for $24-48 \mathrm{~h}$. After incubation, the colonies were counted and then the kinetics of growth inhibition of germ was studied.

\section{Phytochemical screening}

The phytochemicals compounds have been detected in the extract by classical staining tests in chemistry (Harbone, 1973; Chhabra et al., 1984).
The detection of alkaloids was carried out with the reagents of Mayer, Bouchardat and Draggendrof. The reactions with $0.1 \mathrm{~N}$ hydrochloridic acid, made it possible to highlight the flavonoids. The tannins were identified by ferric chloride $1 \%$, ammonia copper sulfate $1 \%$ and lead acetate $10 \%$. Anthracenes were identified by reaction with $0.1 \mathrm{~N}$ sodium hydroxide; glycosides by $\alpha$ naphthol test, saponins by the foams test; sterols and terpenes by the reaction of Liebermann-Buchard.

\section{Statistical analysis}

Data were analyzed by GraphPad Prism 6 software and considered significant for $p<0.05$. It's were expressed in Mean \pm SEM (standard error of the mean).

\section{RESULTS AND DISCUSSION}

\section{Ethnobotanical data collected}

The ethnobotanical study undertaken in this study showed that traditional healers in Togo used $P$. kotschyi to treat hydrocele, fractures, edema, ascites, female infertility, rashes, pruritus, lesions, scabs, nodules or cysts, breast abscesses, anthrax, boils, chancre and tooth decay. Then, the fresh root and bark of $P$. kotschyi are pounded and applied to the scrotum in the treatment of hydrocele. In the case of fractures, the bark of the fresh roots of the plant is crushed with the roots of Piliostigma thonninngii then the paste is applied on the fractured part. The hot residue of leaf decoction is used during rehabilitation. Leaf infusion is administered orally in the treatment of generalized edema, ascites and female infertility. The leaves and bark of the roots of $P$. kotschyi are also pounded together and then applied locally to the diseased parts to treat conditions such as rashes, pruritus, lesions, scabs, nodules or cysts, breast abscesses, anthrax, boils, chancre. The twigs are used as toothpicks to treat tooth decay.

\section{Antimicrobial effects of extracts}

The data from antimicrobial tests proof that $P$. kotschyi roots have antibacterial activity against both $S$. aureus tested. The extracts which resulted in $100 \%$ inhibition at the concentration of $50 \mathrm{mg} \cdot \mathrm{mL}^{-1}$ in the presumptive test were considered effective while the extracts which growth inhibition rates $<100 \%$ were considered inactive (Table 1). However, it should be noted that our fractioned extracts were semi-purified and concentrated less active compounds. S. aureus ATCC 29213, the reference strain was $100 \%$ susceptible to gentamicin, unlike the clinical strain that was insusceptible to growth inhibition which was $<100 \%$ (Table 1). This suggested that the antibacterial activity of $P$. kotschyi roots was more effective when compared to Gentamycin.

The ethanolic and aqueous extracts were selected for the susceptibility study because they are extracted by the polar solvents which are the antibiotics and also related to the solvents in which the roots of $P$. kotschyi are traditionally used. MICs of the aqueous extract of $P$. kotschyi root bark was the same on both strains of $S$. aureus $\left(0.39 \mathrm{mg} \cdot \mathrm{mL}^{-1}\right)$ (Table 2$)$. The ethanolic bark extract was less effective in inhibiting growth of the clinical $S$. aureus strain (MIC $=0.78 \mathrm{mg} \cdot \mathrm{mL}$ ${ }^{1}$ ) (Table 2). In view of MICs, steles of root extracts were less effective when compared to root bark extracts. The MICs of the ethanolic steles root extract were $6.25 \mathrm{mg} \cdot \mathrm{mL}^{-1}$ and $12.5 \mathrm{mg} \cdot \mathrm{mL}^{-1}$, respectively, on the growth of $S$. aureus ATCC 29213 and $S$. aureus (Table 2). The aqueous extract resulted in growth inhibition of $S$. aureus ATCC 29213 and $S$. aureus with MICs of $1.56 \mathrm{mg} \cdot \mathrm{mL}^{-1}$ and $3.12 \mathrm{mg}$ $\mathrm{mL}^{-1}$, respectively (Table 2). Once again the aqueous extract was more effective in growth inhibition of both bacteria. The determination of minimum bactericidal concentrations (MBC) made it possible to assess the bactericidal power of the extracts (Table 3). The ratio MBC.MIC ${ }^{-1}=2$ for ethanolic extracts; which means that these extracts have a bacteriostatic power, they inhibit the growth of the germ without killing it (Table 4). Ethanolic extracts can be used to manage chronicle infections. The aqueous extracts had a bactericidal effect (MBC.MIC ${ }^{-1}$ $=1$ ) and can be used in acute infection to kill bacteria quickly (Table 4). 
Table 1 Growth inhibition rate of S. aureus

\begin{tabular}{|c|c|c|c|c|c|c|c|c|c|c|c|}
\hline & & Hex & $\begin{array}{l}\text { Hex- } \\
\text { AcEt }\end{array}$ & AcEt & $\begin{array}{l}\text { AcEt- } \\
\mathrm{CHCl}_{3}\end{array}$ & $\mathrm{CHCl}_{3}$ & $\begin{array}{l}\mathrm{CHCl}_{3} \\
\text {.EtOH }\end{array}$ & EtOH & $\begin{array}{l}\text { EtOH- } \\
\mathbf{H}_{2} \mathbf{O}\end{array}$ & $\mathrm{H}_{2} \mathrm{O}$ & GM \\
\hline R & S. aureus ATCC 29213 & 80.79 & 93.55 & 99.57 & 100 & 100 & 100 & 100 & 100 & 100 & \\
\hline Barks & S. aureus & 70.45 & 76.21 & 89.07 & 94.65 & 100 & 100 & 100 & 100 & 100 & \\
\hline $\begin{array}{l}\text { Roots } \\
\text { steles }\end{array}$ & $\begin{array}{l}\text { S. aureus ATCC } 29213 \\
\text { S. aureus }\end{array}$ & $\begin{array}{l}69.98 \\
54.17\end{array}$ & $\begin{array}{l}78.15 \\
63.89\end{array}$ & $\begin{array}{l}88.12 \\
75.55\end{array}$ & $\begin{array}{l}95.44 \\
81.08\end{array}$ & $\begin{array}{l}96.32 \\
90.97\end{array}$ & $\begin{array}{l}99.98 \\
92.81\end{array}$ & $\begin{array}{l}100 \\
100\end{array}$ & $\begin{array}{l}100 \\
100\end{array}$ & $\begin{array}{l}100 \\
100\end{array}$ & \\
\hline GM & $\begin{array}{l}\text { S. aureus ATCC } 29213 \\
\text { S. aureus }\end{array}$ & & & & & & & & & & $\begin{array}{c}100 \\
84.25\end{array}$ \\
\hline
\end{tabular}

Table 2 Minimum inhibitory concentrations (MICs)

\begin{tabular}{|c|c|c|c|c|c|c|c|c|c|c|c|}
\hline \multirow[b]{2}{*}{ Extracts } & & \multirow[b]{2}{*}{ Microbial germs } & \multicolumn{9}{|c|}{ Concentrations (mg.mL ${ }^{-1}$ ) } \\
\hline & & & 50 & 25 & 12.5 & 6.25 & 3.12 & 1.56 & 0.78 & 0.39 & 0.19 \\
\hline \multirow{4}{*}{$\begin{array}{l}\text { Roots } \\
\text { Barks }\end{array}$} & & S. aureus ATCC 29213 & + & + & + & + & + & + & + & - & - \\
\hline & EtOH & S. aureus & + & + & + & + & + & + & - & - & - \\
\hline & & S. aureus ATCC 29213 & + & + & + & + & + & + & + & - & - \\
\hline & $\mathrm{H}_{2} \mathrm{O}$ & S. aureus & + & + & + & + & + & + & + & - & - \\
\hline \multirow{3}{*}{$\begin{array}{l}\text { Steles of } \\
\text { roots }\end{array}$} & EtOH & $\begin{array}{l}\text { S. aureus ATCC } 29213 \\
\text { S. aureus }\end{array}$ & $\begin{array}{l}+ \\
+\end{array}$ & $\begin{array}{l}+ \\
+\end{array}$ & $\begin{array}{l}+ \\
-\end{array}$ & $\begin{array}{l}- \\
-\end{array}$ & $\begin{array}{l}- \\
-\end{array}$ & $\begin{array}{l}- \\
-\end{array}$ & $\begin{array}{l}- \\
-\end{array}$ & $\begin{array}{l}- \\
-\end{array}$ & - \\
\hline & & S. aureus ATCC 29213 & + & + & + & + & + & - & - & - & - \\
\hline & $\mathrm{H}_{2} \mathrm{O}$ & S. aureus & + & + & + & + & - & - & - & - & - \\
\hline
\end{tabular}

Table 3 Percent of the Growth Inhibition and Minimum Bactericidal Concentrations (MBCs)

\begin{tabular}{|c|c|c|c|c|c|c|c|c|c|c|}
\hline \multirow[b]{2}{*}{ Extracts } & & \multirow[b]{2}{*}{ Microbial germs } & \multicolumn{8}{|c|}{ Concentration $\left(\mathrm{mg.mL}^{-1}\right)$} \\
\hline & & & 25 & 12.5 & 6.25 & 3.12 & 1.56 & 0.78 & 0.39 & 0.19 \\
\hline \multirow{5}{*}{$\begin{array}{l}\text { Roots } \\
\text { Barks }\end{array}$} & & S. aureus ATCC 29213 & 100 & 100 & 100 & 100 & 100 & 100 & 94.30 & 78.21 \\
\hline & EtOH & S. aureus & 100 & 100 & 100 & 100 & 100 & 99.04 & 91.90 & 74.87 \\
\hline & & S. aureus ATCC 29213 & 100 & 100 & 100 & 100 & 100 & 100 & 100 & 99.76 \\
\hline & $\mathrm{H}_{2} \mathrm{O}$ & S. aureus & 100 & 100 & 100 & 100 & 100 & 100 & 100 & 98.43 \\
\hline & EtOH & $\begin{array}{l}\text { S. aureus ATCC } 29213 \\
\text { S. aureus }\end{array}$ & $\begin{array}{l}100 \\
\mathbf{1 0 0}\end{array}$ & $\begin{array}{c}100 \\
93.21\end{array}$ & $\begin{array}{l}\mathbf{9 8 . 5 6} \\
84.76\end{array}$ & $\begin{array}{l}90.07 \\
68.95\end{array}$ & $\begin{array}{l}85.71 \\
53.22\end{array}$ & $\begin{array}{l}70.99 \\
36.02\end{array}$ & $\begin{array}{l}66.79 \\
00.00\end{array}$ & $\begin{array}{l}57.41 \\
00.00\end{array}$ \\
\hline $\begin{array}{l}\text { Steles of } \\
\text { roots }\end{array}$ & $\mathrm{H}_{2} \mathrm{O}$ & $\begin{array}{c}\text { S. aureus ATCC } 29213 \\
\text { S. aureus }\end{array}$ & $\begin{array}{l}100 \\
100\end{array}$ & $\begin{array}{l}100 \\
100\end{array}$ & $\begin{array}{l}100 \\
100\end{array}$ & $\begin{array}{l}100 \\
\mathbf{1 0 0}\end{array}$ & $\begin{array}{c}\mathbf{1 0 0} \\
80.18\end{array}$ & $\begin{array}{l}96.34 \\
71.06\end{array}$ & $\begin{array}{l}89.54 \\
50.25\end{array}$ & $\begin{array}{l}78.82 \\
39.97\end{array}$ \\
\hline
\end{tabular}

Table 4 Antimicrobial activity

\begin{tabular}{|c|c|c|c|c|c|c|}
\hline Extracts & & Microbial germs & MIC & MBC & $\begin{array}{l}\text { MBC.MIC }^{-1} \\
\text { Ratio }\end{array}$ & $\begin{array}{c}\text { Antimicrobial } \\
\text { activity }\end{array}$ \\
\hline \multirow{4}{*}{$\begin{array}{l}\text { Roots } \\
\text { Barks }\end{array}$} & & S. aureus ATCC 29213 & 0.39 & 0.78 & 2 & \multirow{2}{*}{$\begin{array}{l}\text { Bacteriostatic } \\
\text { Bacteriostatic }\end{array}$} \\
\hline & EtOH & S. aureus & 0.78 & 1.56 & 2 & \\
\hline & & S. aureus ATCC 29213 & 0.39 & 0.39 & 1 & \multirow{2}{*}{$\begin{array}{l}\text { Bactericidal } \\
\text { Bactericidal }\end{array}$} \\
\hline & $\mathbf{H}_{2} \mathbf{O}$ & S. aureus & 0.39 & 0.39 & 1 & \\
\hline \multirow{3}{*}{$\begin{array}{l}\text { Steles of } \\
\text { roots }\end{array}$} & EtOH & $\begin{array}{c}\text { S. aureus ATCC } 29213 \\
\text { S. aureus }\end{array}$ & $\begin{array}{c}6.25 \\
12.50\end{array}$ & $\begin{array}{l}12.50 \\
25.00\end{array}$ & $\begin{array}{l}2 \\
2\end{array}$ & $\begin{array}{l}\text { Bacteriostatic } \\
\text { Bacteriostatic }\end{array}$ \\
\hline & & S. aureus ATCC 29213 & 1.56 & 1.56 & 1 & Bactericidal \\
\hline & $\mathrm{H}_{2} \mathrm{O}$ & S. aureus & 3.12 & 3.12 & 1 & Bactericidal \\
\hline
\end{tabular}

MICs and MBCs were expressed in $\mathrm{mg} \cdot \mathrm{mL}^{-1}$

The kinetics of growth inhibition of both Staphylococci were followed for ethanolic and aqueous extracts of $P$. kotschyi bark in order to determine whether their bactericidal effect is time dependent. The choice of the $2 \mathrm{x}$ MIC concentration in the time-dependent study showed that the aqueous extract was more effective and S. aureus ATCC 29213 was more susceptibility. The aqueous extract exerted a bactericidal effect on S. aureus ATCC 29213 and S. aureus respectively in $4 \mathrm{~h}$ and $5 \mathrm{~h}$ while that of the ethanolic extract arrived late in $6 \mathrm{~h}$ and $7 \mathrm{~h}$ respectively (Figure 1). The results showed that S. aureus ATCC 29213 was more susceptible to extract than the clinical strain. At $4 \mathrm{~h}, \mathrm{~S}$. aureus ATCC 29213 was completely destroyed by the aqueous extract of the root bark while the 
bactericidal effect of the clinical strain with the same extract was completed at about $5 \mathrm{~h}$. The ethanolic extract of the root bark was less effective and resulted in S. aureus ATCC 29213 and S. aureus bactericidal effect. These kinetics of growth inhibition have highlighted the promptness of ethanolic and aqueous extracts in the destruction of bacteria; and increases the use of extracts in the treatment of acute and chronic infections.

Concentraions of extracts $=2 \times$ MICs

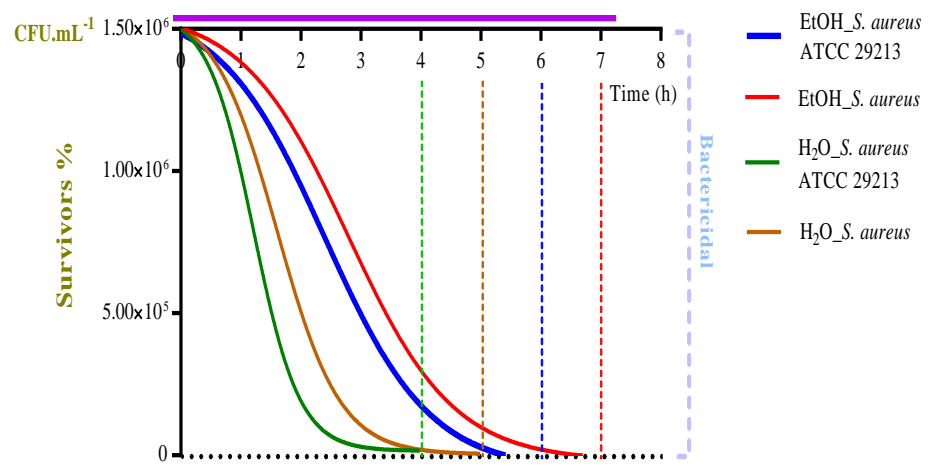

Figure 1 Kinetics of growth inhibition

Inoculum $=1.5 \times 10^{6}$ CFU; EtOH_S. aureus ATCC $29213 /$ S. aureus and $\mathrm{H}_{2} \mathrm{O} \_$S. aureus ATCC 29213 / S. aureus $=$ ethanolic and aqueous extracts of $P$. kotschyi roots barks tested on the both Staphylococci; [EtOH_S. aureus ATCC $29213]=2 \mathrm{MIC}=0.78 \mathrm{mg} \cdot \mathrm{mL}^{-1} ;\left[\mathrm{EtOH} \_\right.$S. aureus $]=2 \mathrm{MIC}=1.56 \mathrm{mg} \cdot \mathrm{mL}^{-1}$; $\left[\mathrm{H}_{2} \mathrm{O} \_\right.$S. aureus ATCC 29213 $]=\left[\mathrm{H}_{2} \mathrm{O} \_\right.$S. aureus ATCC 29213 $]=2 \mathrm{MIC}=0.78$ $\mathrm{mgmL}^{-1}$. CFU $=$ colony format unit

Previous studies on P. kotschyi leaves and stem bark have demonstrated the antibacterial activity of the plant against $S$. aureus. The work of Ayo et al. (2010) showed that $S$. aureus was susceptible to the methanolic extract of $P$. kotschyi leaves $\left(\varnothing=18.00 \mathrm{~mm}\right.$ ) with a MIC of $20 \mathrm{mg} \cdot \mathrm{mL}^{-1}$ and a MBC of $40 \mathrm{mg} \mathrm{mL}^{-1}$. As a result, the leaves had a bacteriostatic effect against $S$. aureus $\left(\mathrm{MBC} . \mathrm{MIC}^{-1}=2\right)$. Alhassan et al. (2014) showed that crude methanolic extracts of $P$. kotschyi stems at $30 \mathrm{mg} \cdot \mathrm{mL}^{-1}$ inhibited the growth of $S$. aureus Methicillin Resistant (MRSA) with $\varnothing=24.00 \mathrm{~mm}, \mathrm{MIC}=7.5 \mathrm{mg} \cdot \mathrm{mL}^{-1}$ and $\mathrm{MBC}=30 \mathrm{mg} \cdot \mathrm{mL}^{-1}$; either a bacteriostatic effect $\left(\mathrm{MBC} \mathrm{MIC}^{-1}=4\right)$. The works of this author confirmed the antibacterial activity of $P$. kotschyi which is also found in steam and the leaves with bacteriostatic power. According to our finding, the root of $P$. kotschyi had a good antibacterial activity against both $S$. aureus which was bactericidal with aqueous extracts.

\section{Phytochemical screening}

The qualitative phytochemical analysis revealed in both extracts the presence of alkaloids, tannins, flavonoids, anthracene, carbohydrates, sterols and saponosides. Terpens were absent (Table 5). The mechanisms by which these extracts exerted their bactericidal effect on the both $S$. aureus strains could be explained by the presence of this phytochemical compound such as flavonoids and tannins. The action mechanism of tannins is complexation either with enzymes or with bacterial substrates or with metal ions or its action on the cell membrane of bacteria (Banso et al., 2007). Flavonoids cause lysis of the membrane and consequently death of the cell (Banso et al., 2007). Other compounds such as alkaloids, saponosides are known to have a curative activity against $S$. aureus (Usman et al., 2007; Jimoh et al., 2017).
Table 5 Phytochemical compound

\begin{tabular}{|c|c|c|c|c|c|}
\hline \multirow{2}{*}{$\begin{array}{l}\text { Phytochemical } \\
\text { compounds }\end{array}$} & \multirow{2}{*}{ Reactions } & \multicolumn{4}{|c|}{ Results } \\
\hline & & $\mathrm{Rb}-\mathrm{EtOH}$ & $\mathrm{Rb}-\mathrm{H}_{2} \mathrm{O}$ & Rs-EtOH & Rs- $\mathrm{H}_{2} \mathrm{O}$ \\
\hline Alkaloids & $\begin{array}{l}\text { Bauchardat } \\
\text { Mayers } \\
\text { Draggendrof }\end{array}$ & $\begin{array}{l}+ \\
+ \\
+\end{array}$ & $\begin{array}{l}+ \\
+ \\
+\end{array}$ & $\begin{array}{l}+ \\
+ \\
+\end{array}$ & $\begin{array}{l}+ \\
+ \\
+\end{array}$ \\
\hline Tannins & $\begin{array}{c}\mathrm{FeCl}_{3} \\
\text { Ammonia copper } \\
\text { sulfate } 1 \% \\
\text { Lead acetate } 10 \%\end{array}$ & $\begin{array}{l}+ \\
+ \\
+\end{array}$ & $\begin{array}{l}+ \\
+ \\
+\end{array}$ & $\begin{array}{l}+ \\
+ \\
+\end{array}$ & $\begin{array}{l}+ \\
+ \\
+\end{array}$ \\
\hline Flavonoids & $\begin{array}{c}\text { Concentrated } \mathrm{HCl} \\
\mathrm{NaOH} 10 \%\end{array}$ & $\begin{array}{l}+ \\
+\end{array}$ & $\begin{array}{l}+ \\
+\end{array}$ & $\begin{array}{l}+ \\
+\end{array}$ & $\begin{array}{l}+ \\
+\end{array}$ \\
\hline Anthracene & $0,1 \mathrm{~N} \mathrm{NaOH}$ & + & + & + & + \\
\hline $\begin{array}{l}\text { Carbohydrates } \\
\text { (oses and osids) }\end{array}$ & $\begin{array}{l}\text { Molisch / } \alpha- \\
\text { Naphthol test }\end{array}$ & + & + & + & + \\
\hline $\begin{array}{l}\text { Terpenes } \\
\text { Sterols }\end{array}$ & Lieberman & - & $\begin{array}{l}- \\
+\end{array}$ & $\begin{array}{l}- \\
+\end{array}$ & $\begin{array}{l}- \\
+\end{array}$ \\
\hline Saponosides & Stirring & + & + & + & + \\
\hline
\end{tabular}

$\mathrm{Rb}=$ Roots bark; $\mathrm{Rs}=$ Roots steles; $\mathrm{H}_{2} \mathrm{O}=$ Water; $\mathrm{EtOH}=$ ethanol; + = presence; - = absence

\section{CONCLUSION}

This work evaluated the antibacterial properties of the root bark and steles of $P$. kotschyi roots. The results obtained proved that the ethanolic and aqueous extracts had antibacterial properties and could be used as a source for the development of new antibiotics. The barks were more effective than steles of the roots, as was the aqueous extract compared to the ethanolic extract. This assumes that traditional healers could optimize the efficacy of $P$. kotschyi in the treatment of $S$. aureus infections using root bark. They can use the aqueous extract in acute infections, then the ethanolic extract in chronic infections. However, further studies are still needed to clarify the physicochemical and pharmacological constants of the active compounds contained in P. kotschyi roots in order to produce improved phytomedicines and their rational use in traditional medicine.

Acknowledgments: Our thanks to the University of Lome and its authorities and the Higher School of Biological and Food Technical (ESTBA), without forgetting the Tradipraticians of the Regions of Central and Plateau especially from the village of Kolocope (Togo) for the facilities provided for the realization of this work.

\section{REFERENCES}

Alhassan, A. M., Malami, I., and Abdullahi, M. I. (2014). Phytochemical Screening and Antimicrobial Evaluation of Stem Bark Extract of Pseudocedrela kotschyi (Schweinf.) Herms. British Journal of Pharmaceutical Research, 4(16), 1937-1944. https://doi.org/10.9734/BJPR/2014/12163

Anani, K., Adjrah, Y., Ameyapoh, Y., Karou, S. D., Agbonon, A., de Souza, C. and Gbeassor, M. (2016). Antimicrobial, anti-inflammatory and antioxidantactivities of Jatropha multifida L. (Euphorbiaceae). Pharmacognosy Research, 8, 142-146. DOI: 10.4103/0974-8490.172657

Asase, A., Oteng-Yeboah, A. A., Odamtten, G. T., \& Simmonds, M. S. (2005). Ethnobotanical study of some Ghanaian anti-malarial plants. Journal of Ethnopharmacology, 99(2), 273-279. https://doi.org/10.1016/j.jep.2005.02.020

Atchou, K., Agban, A., Batawila, K., Karou, S. D., Tchacondo, T., Amadou, S. H., de Souza, C., Gbassor M., and Akpagana, K. (2013). Antimicrobial effects of Lanneakerstingii Engl. and K. Krause (Anacardiaceae). Revue Africaine de Sante et de Productions Animales, 11(2), 121-124.

Ayo, R. G., Audu, O. T., Ndukwe, G. I., and Ogunshola, A. M. (2010). Antimicrobial activity of extracts of leaves of Pseudocedrela kotschyi (Schweinf.) Harms. African Journal of Biotechnology, 9(45), 7733-7777. DOI: 10.5897/AJB10.778 
Azzazi, M. F., Shahin, S. I., Nofal, A. M., and Abd El-Rahman, A. F. (2015). A Preliminary Study on Antimicrobial Activities of Essential Oils and Egyptian Pollen Extract Against some phytopathogenic Fungi and Bacteria. Egypt j. Bot., 2, 363-374.

Banso, A., and Adeyemo, S. O. (2007). Evaluation of antibacterial properties of tannins isolated from Dichrostachyscinerea. African Journal of Biotechnology, 6, 1785-1787. DOI: $10.5897 /$ AJB2007.000-2262

Chhabra, S. C., Uiso, F. C., and Mshiu, E. N. (1984). Phytochemical screening of Tanzanian medicinal plants. I. Journal of ethnopharmacology, 11(2), 157-179. https://doi.org/10.1016/0378-8741(84)90037-0

de Souza, C., Ameganvi, K. K., Koumaglo, K., and Gbeassor M. (1993). Etude de l'activité antimicrobienne des extraits aqueux totaux de dix plantes medecinales. Revue de Médecines et Pharmacopees Africaines, 2(7), 107-115.

Elufioye, T. O., Abdul, A. A., and Moody, J. O. (2017). Cytotoxicity Studies of the extracts, fractions, and isolated Compound of Pseudocedrela kotschyi on Cervical Cancer (HeLa), Breast Cancer (MCF-7) and Skeletal Muscle Cancer (RD) Cells. Pharmacognosy Res., 9(1), 46-50. Doi: 10.4103/0974-8490.199776

Harbone, J. B. (1973). Phytochemical methods. Chapman and hall, Eds. New York 354. Doi: 10.1007/978-94-009-5921-7

Jimoh, S. O., Arowolo, L. A. and Alabi, K. A. (2017). Phytochemical screening and antimicrobial evaluation of Syzygium aromaticum extract and essential oil. International Journal of Current Microbiology and Applied Sciences, 6, 45574567. https://doi.org/10.20546/ijcmas.2017.607.476

Kaouadji, M., Agban, A., Mariotte, A. M., and Tissut, M. (1986). Lonchocarpene, a stilbene and Lonchocarpusone, an isoflavone: two new pyranopolyphenols from Lonchocarpus nicou roots. Journal of Natural Products, 49(2), 281-285. https://doi.org/10.1021/np50044a013

Karou, D., Dicko, M.H., Simpore, J., and Traore, A. S. (2005). Antioxidant and antibacterial activities of polyphenols from ethnomedicinal plants of Burkina Faso. African Journal of Biotechnology, 4, 823-828.

Kassim, O. O., Loyevsky, M., Amonoo, H., Lashley, L., Ako-Nai, K. A., \& Gordeuk, V. R. (2009). Inhibition of in-vitro growth of Plasmodium falciparum by Pseudocedrela kotschyi extract alone and in combination with Fagara zanthoxyloides extract. Transactions of the Royal Society of Tropical Medicine and Hygiene, 103(7), 698-702. https://doi.org/10.1016/j.trstmh.2009.02.018

Mambou, C. S., Nono, R. N., Chouna, J. R., Nkeng-Efouet-Alango, P., \& Sewald, N. (2018). Antibacterial secotirucallane triterpenes from the stem bark of Pseudocedrela kotschyi. Zeitschrift für Naturforschung C, 73(5-6), 241-246. https://doi.org/10.1515/znc-2017-0207

McGuinness, W. A., Malachowa, N., \& DeLeo, F. R. (2017). Focus: infectious diseases: vancomycin resistance in Staphylococcus aureus. The Yale journal of biology and medicine, 90(2), 269.

Ojewale, A. O., Adekoya, A. O., Faduyile, F. A., Yemitan, O. K., and Odukanmi A. O. (2014). Nephroprotective Activities of Ethanolic Roots Extract of Pseudocedrela kotschyi against Oxidative Stress and Nephrotoxicity in Alloxaninduced Diabetic Albino Rats. British Journal of Pharmacology and Toxicology, 5(1), 26-34.

Usman, H., Osuji, J. C. (2007). Phytochemical and in vitro antimicrobial assay of the leaf extract of Newbouldialaevis. The African Journal of Traditional Complementary and Alternative Medicines, 4, 476-480. 